This document is the accepted version of a published work that appeared in final form in Biopolymers (Peptide Science), after technical editing by the publisher. To access the final edited and published work, see https://doi.org/10.1002/bip.22674 
Biopolymers:

Peptide Science

\section{The Fluorescence and Infrared Absorption Probe para- Cyanophenylalanine: Effect of Labeling on the Behavior of Different Membrane-Interacting Peptides}

\begin{tabular}{|c|c|}
\hline Journal: & Biopolymers: Peptide Science \\
\hline Manuscript ID: & BIP-PEP-2015-00021.R1 \\
\hline Wiley - Manuscript type: & Original Article \\
\hline Date Submitted by the Author: & $\mathrm{n} / \mathrm{a}$ \\
\hline Complete List of Authors: & $\begin{array}{l}\text { Bobone, Sara; University of Rome Tor Vergata, Department of Chemical } \\
\text { Sciences and Technologies } \\
\text { De Zotti, Marta; Institute of Biomolecular Chemistry, CNR, Padova Unit, } \\
\text { University of Padova, Department of Chemistry } \\
\text { Bortolotti, Annalisa; University of Rome Tor Vergata, Department of } \\
\text { Chemical Sciences and Technologies } \\
\text { Biondi, Barbara; Institute of Biomolecular Chemistry, CNR, Padova Unit, } \\
\text { University of Padova, Department of Chemistry } \\
\text { Ballano, Gema; University of Padova, Chemistry } \\
\text { Palleschi, Antonio; University of Rome Tor Vergata, Department of } \\
\text { Chemical Sciences and Technologies } \\
\text { Toniolo, Claudio; University of Padova, Chemistry } \\
\text { Formaggio, Fernando; University of Padova, Chemistry } \\
\text { Stella, Lorenzo; University of Rome Tor Vergata, Department of Chemical } \\
\text { Sciences and Technologies }\end{array}$ \\
\hline Keywords: & $\begin{array}{l}\text { alamethicin, para-cyano aromatic probe, fluorescence, infrared absorption, } \\
\text { peptide synthesis }\end{array}$ \\
\hline
\end{tabular}


The Fluorescence and Infrared Absorption Probe para-Cyanophenylalanine: Effect of Labeling on the Behavior of Different Membrane-Interacting Peptides

Sara Bobone, ${ }^{1, \#, \S}$ Marta De Zotti, ${ }^{2, \#}$ Annalisa Bortolotti, ${ }^{1}$ Barbara Biondi, ${ }^{3}$ Gema Ballano, ${ }^{2}$ Antonio Palleschi, ${ }^{1}$ Claudio Toniolo, ${ }^{2,3}$ Fernando Formaggio, ${ }^{2,3,{ }^{*}}$ Lorenzo Stella $^{1, *}$

submitted for the Special Issue of Biopolymers (Pept. Sci.) devoted to the contributions presented at the "Peptides in Paris Symposium-PIPS 2014"

${ }^{1}$ Department of Chemical Sciences and Technologies, University of Rome "Tor Vergata", 00133 Rome, Italy

${ }^{2}$ Department of Chemistry, University of Padova, 35131 Padova, Italy

${ }^{3}$ Institute of Biomolecular Chemistry, Padova Unit, CNR, 35131 Padova, Italy

\footnotetext{
"These authors contributed equally

${ }^{\S}$ Current address: Institute für Biologie, Humboldt - Universität zu Berlin, 10115 Berlin, Germany

* Correspondence to: Lorenzo Stella; e-mail: stella@stc.uniroma2.it and Fernando Formaggio; e-mail: fernando.formaggio@unipd.it
}

John Wiley \& Sons, Inc. 


\begin{abstract}
Total syntheses and complete characterizations of singly substituted $\mathrm{Phe}_{\mathrm{CN}}$-based analogs of alamethicin AlaP, which is active on model and natural membranes, and the TM peptide, which inserts in a transmembrane orientation in lipid bilayers, are reported. The syntheses of the AlaP analogs were performed in solution, while those of TM and its analogs were carried out by solid phase. Using the cyanophenyl fluorescence and IR absorption probe, an in-depth investigation of the self-association, membraneinteracting, permeabilizing, and orientation properties of these peptides were conducted. The aromatic residue incorporated induces only a negligible modification to the properties of the parent peptides. The Phe $_{\mathrm{CN}}$ IR absorption band was located between $2228-2230 \mathrm{~cm}^{-1}$ for all peptides, irrespective of the position of labeling. By contrast, as the width of this band varied significantly with the depth of probe insertion in the bilayer, it could represent a good marker of the Phe ${ }_{\mathrm{CN}}$ position in phospholipid membranes.
\end{abstract}

Keywords: alamethicin, para-cyano aromatic probe; fluorescence; infrared absorption; peptide synthesis. 


\section{INTRODUCTION}

Phe $_{\mathrm{CN}}$ is an $\alpha$-amino acid with interesting IR absorption and emission (in the UV region) properties. ${ }^{1-27}$ Its IR absorption band is centered at approximately $2230-2240 \mathrm{~cm}^{-1}$, i.e. in a spectral region completely free of overlap with other bands. In addition, the position of this band is sensitive to the environment. In particular, it is dependent on the local electric field, and thus on polarity. The maximum shifts from 2237.2 $\mathrm{cm}^{-1}$ (FWHM $9.8 \mathrm{~cm}^{-1}$ ) in water to $2228.5 \mathrm{~cm}^{-1}$ (FWHM $5.0 \mathrm{~cm}^{-1}$ ) in tetrahydrofuran. For this reason, it has been used as an environmental probe in studies of protein and peptide conformations and interactions. In particular, a few investigations reported the IR absorption properties of the Phe $\mathrm{CN}_{\mathrm{CN}}$ probe for peptides associated to bicelles ${ }^{15}$ or phospholipid membranes. ${ }^{3,25,27}$ However, a simplistic analysis of the band properties in terms of local electric field is not warranted, because of the additional dependence of the IR absorption peak on $\mathrm{H}$-bond formation, solvent dynamics and other more complex electrostatic interactions. ${ }^{28,29}$ Also the fluorescence properties of $\mathrm{Phe}_{\mathrm{CN}}$ are useful. In water, its quantum yield is 0.11, compared to 0.025 for the extremely weak Phe emission. In addition, this parameter is strongly sensitive to the environment, $\mathrm{H}$-bond formation, and the presence of $\mathrm{Cl}^{-}$and other ions. For instance, the quantum yield and lifetime of $\mathrm{Phe}_{\mathrm{CN}}$ decrease dramatically in apolar environments. These properties can be exploited to follow peptide aggregation or water-membrane partition, but, at the same time, they might somehow hamper the application of the fluorescence of this probe in the characterization of peptides inserted inside membranes. Finally, compared to other fluorescent or IR extrinsic probes, $\mathrm{Phe}_{\mathrm{CN}}$ is rather noninvasive, as it is an amino acid which sterically is very similar to Tyr.

The present study is aimed at defining the usefulness of $\mathrm{Ph}_{\mathrm{CN}_{\mathrm{N}}}$ in studies of membrane-interacting peptides. One of the most important properties of a spectroscopic probe is a minimal perturbation of the behavior of the system where it is introduced. This characteristic is vital for peptides, since probe-induced perturbations might be particularly relevant for these relatively small biomolecules. To test this aspect for Phe $_{\mathrm{CN}}$, we concentrated on labeled analogs of two membrane-interacting peptides that had previously been extensively characterized: (i) the peptaibiotic ${ }^{30,31}$ alamethicin, ${ }^{32-54}$ rich in the strongly helicogenic Aib residues, ${ }^{55-60}$ the second compound of this class, after trichogin, ${ }^{61-63}$ to be labeled with a para-cyano aromatic probe, ${ }^{26,27}$ and (ii) a model helical peptide (TM), ${ }^{64}$ which has been demonstrated to reliably insert in a trans-membrane orientation. The sequences and acronyms of the compounds investigated are reported in Table I. The alamethicin analog AlaP, which we showed in a previous study to behave similarly to the naturally-occurring peptaibiotic, ${ }^{36,37}$ was labeled at three different positions $(4,9$, and 15 , i.e. near the $\mathrm{N}$-terminus, in a central position, and near the $\mathrm{C}$-terminus, respectively) along its main chain. For the TM peptide analogs, the probe was inserted at position 3 (peptide TM3) or 11 (peptide TM11), which should be positioned in a very different membrane environment when the peptides insert in a transmembrane orientation. In particular, considering the known helical conformation of $\mathbf{T M}{ }^{64}$ the probe would be located at approximately 15 and $3 \AA$ from the center of the bilayer for TM3 and TM11, 
respectively. These variants will allow an assessment of the sensitivity of the spectroscopic properties of the probe to the depth of its immersion in the membrane. In all analogs Phe $_{C_{N}}$ replaces an apolar residue (Ala, Val or Leu). A preliminary report of a limited part of this work was already presented. ${ }^{26}$

\section{MATERIALS AND METHODS}

\section{Abbreviations and Materials}

Ac, acetyl; Aib, $\alpha$-aminoisobutyric acid; ATR, attenuated total reflectance; Boc, tert-butyloxycarbonyl; CD, circular dichroism; CF, carboxyfluorescein; DCM, dichloromethane; DIEA, diisopropylethylamine; DMF, N,Ndimethylformamide; EDC, N-ethyl, N'-[3-(dimethylamino)propyl]carbodiimide; ESI-MS, electrospray ionization-mass spectrometry; Fmoc, 9-fluorenylmethyloxycarbonyl; FT, Fourier transform; FWHM, full width at half maximum; HATU, O-(7-azabenzotriazol-1-yl)-1,1,3,3-tetramethyluronium hexafluorophosphate; HBTU, O-(benzotriazol-1-yl)-1,1,3,3-tetramethyluronium hexafluorophosphate; HOAt, 7-aza-1-hydroxy-benzotriazole; HOBt, 1-hydroxy-benzotriazole; IR, infrared; LL, low loading; MBHA, 4-methyl-benzhydrylamine; MS, mass spectrometry; MW, molecular weight; NMM, N-mehylmorpholine; OAll, allyloxy; OBzl, benzyloxy; OMe, methoxy; Phe $_{\mathrm{CN}}$, para-cyanophenylalanine; PEG, polyethylene glycol; Phol, phenylalaninol; POPC, 1-palmitoyl-2-oleoyl-sn-glycero-3-phosphocholine; RP-HPLC, reverse-phase high performance liquid chromatography; SDS, sodium dodecyl sulphate; SPPS, solid-phase peptide synthesis; TIS, triisopropylsilane; TFA, trifluoroacetic acid.

All amino acids and derivatives used, including Fmoc-Lys(Boc)-OH, were of $\mathrm{L}$ - configuration and purchased from IRIS Biotech (Marktredwitz, Germany) or Sigma-Aldrich (St. Louis, MO). EDC, HOBt, HOAt, HATU, and HBTU were GL Biochem (Shanghai, China) products. SDS was obtained from Acros (Geel, Belgium). POPC was purchased from Avanti Lipids (Alabaster, AL). All other chemicals were obtained from Sigma-Aldrich (St. Louis, MO). Spectroscopic grade solvents were used in all CD and fluorescence experiments. ESI-MS data were recorded on a PerSeptive Biosystem Mariner Instrument (Farmingham, MA).

\section{Peptide Synthesis in Solution}

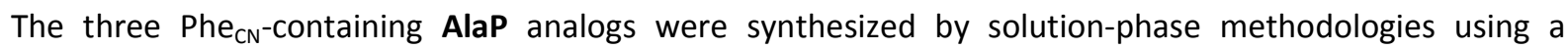
combination of step-by-step and segment condensation approaches. As an example, the strategy followed for the synthesis of AlaP is reported in Scheme 1. All synthetic intermediates were fully characterized by physical and analytical techniques (Supporting Information). 


\section{Solid-Phase Peptide Synthesis}

Assembly by automatic SPPS of the three TM peptides on the Advanced ChemTech (Louisville, KY) $348 \Omega$ peptide synthesizer was performed on a $0.03 \mathrm{mmol}$ scale by the FastMoc methodology [HBTU, ${ }^{65} \mathrm{HOBt},{ }^{66}$ DIEA, double acylation protocol, 45 min coupling time, N-methylpyrrolidin-2-one as the solvent], using the Rink Amide MBHA LL resin (Novabiochem, Darmstadt, Germany) (100 mg, loading $0.30 \mathrm{mmol} \mathrm{g}^{-1}$ ). Removal of the Fmoc group was performed with a 20\% piperidine solution in DMF in two steps of 5 and 15 min, respectively. The chromatographically purified, final peptides were fully characterized (Supporting Information).

\section{UV-Vis Absorption}

UV-vis absorption measurements were carried out on a Cary 100 Scan (Varian, Palo Alto, CA) spectrophotometer. Molar concentrations of the labeled analogs were determined in $\mathrm{MeOH}$ solution at $\lambda=280 \mathrm{~nm}\left[\text { Phe }_{\mathrm{CN}} \text { absorption, } \varepsilon(280 \mathrm{~nm})=850 \mathrm{M}^{-1} \mathrm{~cm}^{-1}\right]^{5}$

\section{Circular Dichroism}

CD measurements were carried out on a Jasco J-715 spectropolarimeter. The CD spectra were acquired and processed using the J-700 program for Windows. All spectra were recorded at room temperature, using Hellma quartz cells with Suprasil windows and optical path lengths of $0.1 \mathrm{~cm}$. The signal-to-noise ratio was improved by accumulating eight scans. The values are expressed in terms of total molar ellipticity, $[\theta]_{\mathrm{T}}$ $\left[\mathrm{deg} \cdot \mathrm{cm}^{2} \cdot \mathrm{dmol}^{-1}\right]$. MeOH and $100 \mathrm{mM}$ aqueous SDS were used as solvents.

\section{Steady-State Fluorescence}

Fluorescence experiments were performed on a Fluoromax-4 fluorimeter (Horiba-Jobin Yvon, France), under the following conditions: $\lambda_{\text {exc }}=240 \mathrm{~nm}$, bandpass: $10 \mathrm{~nm}$ in excitation, $2 \mathrm{~nm}$ in emission; integration time $=2 \mathrm{~s}$, peptide concentration $=1 \mu \mathrm{M} ; \mathrm{T}=25^{\circ} \mathrm{C}$.

\section{Time-Resolved Fluorescence}

Fluorescence intensity decays were measured on an Edinburgh Instruments [Edinburgh, UK], timecorrelated single photon counting setup, using a nanosecond flash-lamp filled with nitrogen for excitation. Experimental conditions: $\lambda_{\mathrm{exc}}=240 \mathrm{~nm} ; \lambda_{\mathrm{em}}=295 \mathrm{~nm}$, interval: $50 \mathrm{~ns}$, channels: 1024 , bandwidth: $10 \mathrm{~nm}$.

\section{Liposome Preparation}

Large unilamellar vesicles were prepared as previously described, ${ }^{67}$ by dissolving POPC lipids in a 1:1 ( $\mathrm{vol} / \mathrm{vol})$ methanol/chloroform solution, in an appropriate amount to obtain a final stock solution of liposomes with a lipid concentration of $5 \mathrm{mM}$. The solvents were evaporated under reduced argon 
atmosphere until a thin film was formed. Complete evaporation was ensured by applying a rotary vacuum pump for at least $2 \mathrm{hr}$. The lipid film was hydrated with a $10 \mathrm{mM}$ phosphate buffer (pH 7.4), $140 \mathrm{mM} \mathrm{NaCl}$ and $0.1 \mathrm{mM}$ EDTA (buffer A, used for water-membrane partition experiments) or with a CF solution prepared by dissolving the dye powder in a minimum amount of $0.1 \mathrm{M} \mathrm{NaOH}$, and then diluting to $30 \mathrm{mM}$ CF in $10 \mathrm{mM}$ phosphate buffer ( $\mathrm{pH} 7.4$ ), $80 \mathrm{mM} \mathrm{NaCl}$ and $0.1 \mathrm{mM}$ EDTA (for membrane perturbation experiments). ${ }^{68}$ The iso-osmolarity of these solutions was checked with a freezing point depression osmometer (Fiske-Advanced Instruments, Norwood, USA). After vigorous stirring and 10 freeze and thaw cycles, the liposome suspension was extruded for 31 times through two stacked polycarbonate membranes (Avestin, Ottawa, ON, Canada) with pores of $100 \mathrm{~nm}$ or $200 \mathrm{~nm}$ diameter (see below). The unencapsulated fluorescent tracer was separated from the liposomes by gel filtration on a Sephadex G-50 medium column $(40 \mathrm{~cm})$ in buffer A. Lipid concentration in the final sample was determined by the Stewart method. ${ }^{69}$

\section{Water-Membrane Partition}

Water-membrane partition experiments were performed by titrating a $1 \mu \mathrm{M}$ peptide solution (in buffer A) with increasing amounts of a lipid vesicles solution, and by following the variation in the emission intensity . The cuvette was pretreated for $30 \mathrm{~min}$ with a $5 \%(\mathrm{w} / \mathrm{w})$ solution of PEG, to avoid peptide adsorption to the quartz walls. The fraction of peptide associated with membranes was calculated from the fluorescence intensity at $292 \mathrm{~nm}(F)$, according to the following equation:

$$
f=\frac{F-F_{M}}{F_{M}-F_{W}}
$$

where $F_{W}$ and $F_{M}$ represent the fluorescence intensities of the peptide in water and in the membrane, respectively. The value of $F_{M}$ was extrapolated by a double reciprocal plot of $1 / F$ vs $1 /[P O P C]$. The partition curve was fit with the following equation: ${ }^{70,71}$

$$
f=\frac{K_{P} \frac{[P O P C]}{55.3 M}}{1+K_{P} \frac{[P O P C]}{55.3 M}}
$$

where $55.3 \mathrm{M}$ is the molarity of pure water at $25^{\circ} \mathrm{C}$, and $K_{P}=\frac{x_{p}^{L}}{x_{p}^{W}}$ is the partition constant defined as the ratio of molar fractions of the peptide in the lipid and water phases at equilibrium. ${ }^{67,70}$ Since the partition data were essentially superimposable for the different alamethicin analogs, they were fit globally with a single curve, yielding $K_{P}=4.010^{3}$. Experimental conditions: [POPC] $=$ from 0.1 to $50 \mu \mathrm{M} ; \lambda_{\text {exc }}=240 \mathrm{~nm}$; bandpass $3 \mathrm{~nm}$ in excitation and $5 \mathrm{~nm}$ in emission; liposome diameter: $100 \mathrm{~nm} ; \mathrm{T}=25^{\circ} \mathrm{C}$. The background due to liposome scattering was subtracted from each spectrum. 


\section{Membrane-Perturbing Activity}

CF-loaded liposomes (with 200-nm diameter) were used to assess the membrane-perturbing activity of the compounds. The peptide-induced leakage from vesicles was measured $20 \mathrm{~min}$ after peptide addition. The leaked fraction was calculated as

$$
R=\frac{F-F_{0}}{F_{100}-F_{0}}
$$

where $F_{0}$ is the CF signal before peptide addition, and $F_{100}$ is the intensity after the addition of a detergent, triton-X100 $1 \mathrm{mM}$, which causes complete lysis of membranes. $F$ is the fluorescence value obtained 20 min after peptide addition. ${ }^{72,73}$ Experimental conditions: $\lambda_{\mathrm{exc}}=490 \mathrm{~nm}$ (bandwidth $0.2 \mathrm{~nm}$ ); $\lambda_{\mathrm{em}}=520 \mathrm{~nm}$ (bandwidth $1.5 \mathrm{~nm}$ ); [POPC]: $20 \mu \mathrm{M} ; \mathrm{T}=25^{\circ} \mathrm{C}$.

\section{Fluorescence Quenching}

Fluorescence quenching data were analyzed according to a model with two sub-populations of the peptide, contributing to the overall fluorescence with fractions $f_{1}$ and $f_{2}=1-f_{1}$, and different accessibilities to the quencher, resulting in different values for the Stern-Volmer constants, $K_{1}$ and $K_{2}:^{74}$

$$
\frac{F_{0}}{F}=\left\{\frac{f_{1}}{1+K_{1}[Q]}+\frac{1-f_{1}}{1+K_{2}[Q]}\right\}^{-1}
$$

The following values were derived for the experiments performed with the TM analogs:

TM3: $f_{1}=0.42 \pm 0.01, K_{1}=3.3 \pm 0.9 \mathrm{mM}^{-1}, K_{2}=(1.9 \pm 0.6) 10^{-3} \mathrm{mM}^{-1}$.

TM11: $f_{1}=0.36 \pm 0.01, K_{1}=0.46 \pm 0.05 \mathrm{mM}^{-1}, K_{2}=0 \mathrm{mM}^{-1}$.

\section{ATR-FTIR Absorption}

Infrared absorption measurements were performed on a Nicolet FTIR spectrometer (Thermo Electron Co., Madison, WI) in the ATR mode. A 1:1 chloroform/methanol solution of POPC and peptide (1.5 $\mu$ moles of POPC with 5\%, or 15\% molar fraction of peptide, for TM and AlaP analogs, respectively) was spread onto a $8 \times 1 \times 0.3 \mathrm{~cm}$ Ge crystal (reflection angle $45^{\circ}, 12$ reflections on the sample surface). The total solution volume was $130 \mu \mathrm{l}$. The crystal was dried under a gentle Ar stream and then put under vacuum for $2 \mathrm{hr}$ to completely remove the organic solvents. The sample was hydrated by placing a water-containing vessel into a gas-tight chamber onto the Ge crystal. Spectra were acquired every hour for 8-12 hr. After the first 2 $\mathrm{hr}$, no modifications in the position or intensities of the bands were revealed during the experiment, indicating the attainment of equilibrium in hydration. ATR spectra were acquired under the following conditions: $2 \mathrm{~cm}^{-1}$ resolution, 128 acquisitions ( 256 for the polarized spectra). The FWHM of the cyano peak was determined by fitting the absorption band to a Gaussian function.

For polarized ATR experiments, the ATR electric fields of the incident light were calculated considering a refractive index of 4 for Ge and of 1.44 for the lipids. ${ }^{75}$ Calculations of peptide orientation were carried out 
in the thick film approximation, considering that the dichroic ratio of symmetric lipid $\mathrm{CH}_{2}$ stretching bands is always higher than $1.41 .^{75}$ This finding is consistent with the amount of lipids spread on the film, which, considering an area per lipid of $0.68 \mathrm{~nm}^{2},{ }^{76}$ is sufficient to form more than 350 bilayers on the crystal surface. With a bilayer spacing of $6.4 \mathrm{~nm}$ at full hydration, ${ }^{76}$ it corresponds to a thickness of more than 2 $\mu \mathrm{m}$, to be compared with a calculated penetration depth $(d p) .{ }^{75}$ This parameter can be obtained according to the following equation: $:^{75}$

$$
d p=\frac{\lambda}{2 \pi \sqrt{\left(n_{1} \sin \vartheta\right)^{2}-\left(n_{2}\right)^{2}}}
$$

where $\lambda$ is the wavelength ( $6 \mu \mathrm{m}$ for the amide I band), $n_{1}$ and $n_{2}$ are the refractive indexes of Ge (4.0) and lipids (1.44), respectively, and $\vartheta$ is the reflection angle of the crystal $\left(45^{\circ}\right)$. Therefore, in our case $d p=0.4$ $\mu \mathrm{m}$ and a sample thicker than $2 \mu \mathrm{m}$ fully justifies the thick film approximation. ${ }^{75}$

The order parameter $\mathrm{S}$ was derived from the following equation: $:^{37,75}$

$$
R=\frac{E_{X}^{2}}{E_{Y}^{2}}+\frac{E_{Z}^{2}}{E_{Y}^{2}}\left(1+\frac{3 S}{1-S}\right)
$$

$\mathrm{R}=\mathrm{A}_{\|} / \mathrm{A}_{\perp}$ is the dichroic ratio of the peptide amide I band calculated by integrating the absorbance measured between 1600 and $1700 \mathrm{~cm}^{-1}$ with light polarized parallel $\left(A_{\|}\right)$and perpendicular $\left(A_{\perp}\right)$ to the incidence plane. The three components of the electric fields are given by $E_{x}=1.40, E_{y}=1.52, E_{z}=1.62,{ }^{75}$ and $S$ corresponds to

$$
S=\frac{3<\cos ^{2} \alpha>-1}{2} \frac{3<\cos ^{2} \beta>-1}{2}
$$

where $\alpha$ is the angle between the helix axis and the membrane normal, and $\beta$ is the angle between the transition dipole of the IR absorption band and the helix axis. In the case of helical peptides, the value of $\beta$ can be taken equal to $38^{\circ} .{ }^{75}$

\section{RESULTS AND DISCUSSION}

\section{Synthesis of the AlaP Analogs in Solution}

The syntheses of the AlaP analogs are complicated by the presence of two Aib-Pro tertiary amide bonds in the sequences and the limited reactivity of the eight sterically hindered, $C^{\alpha}$-tetrasubstituted Aib residues, particularly at their $\mathrm{N}$-side. ${ }^{36,77-80}$ However, luckily under the coupling conditions used the $-\mathrm{OH}$ function of the C-terminal Phol 1,2-aminoalcohol is known to be extremely poorly reactive. ${ }^{36}$

In the present work, we applied our published synthetic strategy for the solution synthesis of AlaP analogs, ${ }^{36}$ slightly modifying it to insert the residue containing the para-cyanoaromatic probe. Briefly, the 
sequence was divided into three segments (A, B, and $\mathbf{C}$ ) (Schemes 1 and 2 ) at the level of the Aib-Ala and Aib-Pro bonds. The segments were synthesized step-by-step and eventually condensed to afford the final AlaP analogs. The protecting groups were chosen to minimize the reaction time and to avoid the use of strong reductive conditions in the presence of the sensitive cyano group. The activating agents for the coupling reactions (EDC/HOAt) ${ }^{81}$ were selected by taking into account the low reactivity of the Aib residue. The sequences of the three analogs were split as reported in Scheme 2. The reaction yields of the several synthetic steps were from moderate to good. Eventually, we obtained our target AlaP analogs in good amounts (about $100 \mathrm{mg}$ each) and purity (>96\%).

\section{Solid-Phase Synthesis of the TM Analogs}

In the two analogs of the 24-mer TM peptide the $\mathrm{Phe}_{\mathrm{CN}}$ residue was introduced near the $\mathrm{N}$-terminus (position 3) and in the central region (position 11), respectively, in both cases replacing a similarly hydrophobic Leu residue (Table I).The three syntheses were performed in parallel. The Rink Amide MBHA LL resin and our protocol were chosen to better avoid peptide aggregation. As for the latter: (1) Fmoc deprotection of the $\mathrm{N}^{\alpha}$-function was achieved with a $20 \%$ piperidine solution in DMF in two steps of 5 and $15 \mathrm{~min}$ each. The reaction times were extended to 10 and $25 \mathrm{~min}$, respectively, for the two Lys residues at positions 1 and 2 in the sequence. (2) Coupling reactions (each repeated twice) were carried out using the standard activation method via HBTU/HOBt. ${ }^{65,66}$ (3) N-Terminal acetylation of the final $\mathrm{N}^{\alpha}$-deprotected peptides was performed by two treatments with acetic anhydride and DIEA in DMF for 30 min each. (4) Cleavage of the peptides from the resin was obtained using a TFA/ $\mathrm{H}_{2} \mathrm{O} / \mathrm{TIS}$ mixture $(95: 5: 5 \mathrm{v} / \mathrm{v}, 5 \mathrm{ml} / 100 \mathrm{mg}$ of peptide resin, $2 \mathrm{hr}$ at room temperature). The solution was concentrated and the peptide precipitated by addition of diethyl ether. The desired final peptides were isolated in 75-80\% average yield. Subsequently, the crude peptides were purified by semi-preparative HPLC using a Vydac column and characterized by analytical RP-HPLC and ESI-MS (Supporting Information).

\section{Spectroscopic Properties of the Phe $\mathrm{CN}_{\mathrm{C}}$-Labeled Peptides}

All analogs exhibit the typical fluorescence and IR absorption spectra of the Phe CN $_{\text {probe }}$

Figure 1 shows the normalized fluorescence spectra of the AlaP analogs at a $1 \mu \mathrm{M}$ concentration in an aqueous buffer composed of $10 \mathrm{mM}$ phosphate buffer, $140 \mathrm{mM} \mathrm{NaCl}$, and $0.1 \mathrm{mM}$ EDTA (pH 7.4). The same buffer was used in all of the following experiments. Spectra show the typical shape of Phe $\mathrm{CN}_{\mathrm{CN}}$ emission, with a maximum at $293 \mathrm{~nm}$. No differences among the analogs were found. Similar spectra were obtained for all three TM peptides (data not shown). The IR absorption band of the $\mathrm{C} \equiv \mathrm{N}$ probe for Ala9 in $\mathrm{MeOH}$ exhibits wavelength maximum and FWHM value comparable to those of the isolated amino acid $(2231 \pm 12$ and $2232 \pm 11 \mathrm{~cm}^{-1}$, respectively). 


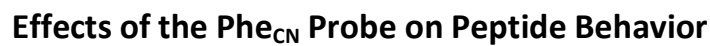

Phe ${ }_{C N}$ does not perturb the peptide secondary structure

The secondary structure of all peptides in $\mathrm{MeOH}$ and in the membrane-mimicking SDS environment was characterized by use of far-UV CD (Figure 2). All spectra indicate a predominantly right-handed helical conformation, ${ }^{82-85}$ which is similar to those of the parent peptides, suggesting that the probe does not significantly affect peptide conformation. The remarkably different ellipticity ratios ( $R$ values) at $222 \mathrm{~nm}$ versus $208 \mathrm{~nm}^{84,85}$ for all peptides, higher in SDS micelles (particularly for the AlaP analogs), point to a significant increase of the $\alpha$-helix percentage at the expenses of the $3_{10}$-helix under the latter condition. The contributions of the aromatic toluene-based Phol and $\mathrm{Phe}_{\mathrm{CN}}$ chromophores to the $\mathrm{CD}$ curves in this spectral region $^{82,83}$ do not seem to complicate the interpretation of the spectroscopic results.

Phe ${ }_{C N}$ does not perturb the aggregation of the AlaP peptides in water

The parent, unlabeled peptide AlaP was previously demonstrated to aggregate in water. ${ }^{37}$ To test whether the introduction of the Phe $\mathrm{CN}_{\mathrm{CN}}$ probe in place of an Ala or Val residue would significantly perturb peptide aggregation in water, we exploited the fluorescence properties of the probe to assess the self-association behavior of the three analogs. Fluorescence intensity decays were measured at increasing peptide concentrations in the presence of quenching $\mathrm{Cl}^{-}$ions ${ }^{86}(140 \mathrm{mM} \mathrm{NaCl})$. Since these anions quench the fluorescence of Phe $\mathrm{CN}_{\mathrm{CN}}$ collisionally, we expected a significantly different fluorescence lifetime for monomers and aggregates (where the fluorophores are partially shielded from the solvent). Indeed, the $P \mathrm{P}_{\mathrm{CN}}$ decays of each alamethicin analog at different concentrations (Figure 3) could be analyzed globally as the sum of two exponentials, with a global reduced chi square always lower than 1.2. The two components likely correspond to the monomeric peptide (short lifetime, i.e. $3.4 \pm 0.6 \mathrm{~ns}, 4.0 \pm 0.2 \mathrm{~ns}$ and $4.0 \pm 0.2 \mathrm{~ns}$ for Ala4, Ala9 and Ala15, respectively) and aggregated species (long lifetime, i.e. $10.0 \pm 0.5 \mathrm{~ns}, 11.0 \pm 0.4 \mathrm{~ns}, 10.1 \pm$ 0.7 ns for Ala4, Ala9 and Ala15, respectively). Therefore, the pre-exponential factor of the long lifetime provides a measure of the population of the aggregated species (Figure 4). The behavior of the three analogs is quite similar. In particular, they exhibit a strong tendency to aggregate. Monomers are practically absent already at a concentration of $10 \mu \mathrm{M}$ (Figure 4). This aggregation behavior is strongly reminiscent of that previously determined for the parent peptide AlaP by CD measurements, ${ }^{37}$ indicating that no significant perturbation is introduced by the Phe $_{\mathrm{CN}}$ fluorophore, except for a slightly higher tendency to aggregate for the Ala to Phe $_{\mathrm{CN}}$ substituted analog.

Phe ${ }_{C N}$ does not perturb the peptide affinity of the AlaP peptides for membranes

Peptide-membrane interaction is a fundamental step in the activity of membrane-active peptides. Therefore, we checked whether Phe $\mathrm{CN}_{\mathrm{CN}}$ introduction would perturb the affinity of the AlaP analogs for lipid bilayers, the membrane-binding affinity of which was determined previously. ${ }^{37}$ Experimentally, peptide 
1

2

3

4

5

6

association to membranes was followed by variation in the fluorescence intensity of the Phe $\mathrm{CN}_{\mathrm{N}}$ probe. The emission spectra of Ala15 in the absence and presence of increasing amounts of lipid vesicles are reported in Figure 5. Similar spectra were obtained for Ala4 and Ala9 (data not shown). The intensity in water is higher than that in the membrane, probably due to $\mathrm{H}$-bond formation by the cyano group in water. ${ }^{12}$ The partition curve resulted to be essentially the same for all of the analogs (Figure 6), notwithstanding the different position of the probe in the sequence. This finding once more indicates that perturbations introduced by Phe $\mathrm{CN}_{\mathrm{C}}$ are negligible.

Phe ${ }_{C N}$ does not perturb the membrane permeabilizing activity of the AlaP peptides

A more stringent, overall test of peptide behavior in the membrane is provided by its membrane permeabilizing activity, which is mediated by both aggregation and lipid binding equilibria. ${ }^{37}$ CF-loaded liposomes were used to assess the membrane-perturbing activity of the analogs. The fraction of liposome contents leaked 20 minutes after peptide addition is reported in Figure 7. All peptides exhibit a behavior very close to that of the parent peptide AlaP, confirming that the probe does not interfere with peptide activity.

Phe ${ }_{C N}$ does not perturb the trans-membrane insertion of the TM analogs

The transmembrane orientation of the TM analogs labeled with PheCN was studied by fluorescence quenching and polarized ATR-FTIR experiments. Quenching by chloride ions ${ }^{13,14}$ of the peptides embedded inside lipid vesicles [50 $\mu \mathrm{M}$ lipids and $3 \mu \mathrm{M}$ peptide] is reported in Figure 8. The nonlinear behavior of the Stern-Volmer plots indicates a heterogeneity in the probe accessibility, and was fit with a model having two sub-populations of the peptide with different accessibilities of the Phe $_{\mathrm{CN}}$ residue to the quencher (see Materials and Methods). In any case, TM3 is much more sensitive to the $\mathrm{Cl}^{-}$ions than TM11, showing that the Phe $_{\mathrm{CN}}$ probe inserted at position 3 is more exposed to the water phase and corroborating our view of its more superficial positioning. Polarized ATR spectra of the amide I absorption band confirmed the transmembrane orientation of the TM analogs. The ratio of absorbance values measured with a polarization parallel and perpendicular to the incidence plane (dichroic ratio) indicates a cosine squared of the angle between the peptide helix and the bilayer normal of about 0.7 (see Materials and Methods), which corresponds to an average angle of about $30^{\circ}$ (Figure 9).

\section{Sensitivity of the Phe $\mathrm{C}_{\mathrm{CN}}$ IR Absorption Band to the Depth of Peptide Insertion in the Membrane}

The experiments reported earlier in the text indicate that the $\mathrm{Ph}_{\mathrm{CN}}$ fluorescence can be usefully employed to study peptide aggregation, membrane binding, and position in the bilayer. Based on these findings, the TM analogs can be considered as a sort of calibration for the sensitivity of the cyano IR absorption band to the depth of the peptide insertion in the membrane. To study the IR absorption properties of the Phe $\mathrm{CN}_{\mathrm{C}}$ 
probe in membranes, the ATR-FTIR spectra of the AlaP and TM analogs were recorded in supported POPC bilayers. As an example, the overall spectrum of Ala15 (P/L=15\%) is illustrated in Figure 10, while the Phe $\mathrm{CN}_{\mathrm{CN}}$ band is shown in Figure 11 for both TM3 and TM11. Peak position and width are reported in Table 2 for all analogs. Surprisingly, irrespective of the specific peptide and the labeling position, the band peak is located in a very narrow interval (approximately between 2228 and $2230 \mathrm{~cm}^{-1}$ ), i.e. in a range corresponding to the values observed for aprotic solvents. ${ }^{29}$ Also the few previous studies on the IR absorption properties of Phe $_{\mathrm{CN}}$-labeled peptides interacting with membrane-mimicking environments reported similar spectra, ${ }^{3,15,25,27}$ even when other evidence pointed towards a significant solvent exposure of the residue. ${ }^{3,25}$ Further studies will be needed to understand why this type of probe inserted at varying membrane depths does not sense a different environment, since in a lipid bilayer the local polarity and water penetration change from the bilayer surface down to less than $1.5 \mathrm{~nm}$ from the membrane center. ${ }^{87,88}$ However, the position of the aromatic $C \equiv N$ IR absorption band is influenced by several factors, including local electric field and hydrogen bonding, ${ }^{29}$ which in the complex environment of the membrane might combine to produce the observed lack of sensitivity to the depth of insertion in the bilayer.

Variations in the width of the absorption band are much more significant, since the FWHM for TM3 is almost twice that of TM11. This finding suggests that the bandwidth decreases with the depth of insertion, and is consistent with experiments in pure solvents, , which reported a width of $10 \mathrm{~cm}^{-1}$ in water and $5 \mathrm{~cm}^{-1}$ in tetrahydrofuran. ${ }^{1}$ In addition, previous investigations on cationic peptides bound to the surface of the membrane ${ }^{3}$ and on peptides reminiscent of the TM analogs investigated here, but inserted in bicelles rather than in lipid bilayers, ${ }^{15}$ reported a similar trend of reduction in IR absorption bandwidth upon membrane insertion.

A large bandwidth was observed for all membrane-associated AlaP analogs, which indicates a peptide location relatively close to the membrane surface. The orientation of alamethicin in membranes has been the object of multiple studies, which overall point to a concentration-driven transition from a superficial peptide location to a transmembrane arrangement. However, the exact orientation is strongly dependent on several aspects of the sample, including degree of hydration, lipid composition, temperature, and $\mathrm{pH} .{ }^{34,89-92}$ In addition, in the absence of a transmembrane potential, the peptide C-terminus is always exposed to the solvent. ${ }^{37}$ Therefore, it is possible that, under the experimental conditions employed in this study, the Phe $\mathrm{CN}_{\mathrm{N}}$ probe in the AlaP analogs locates close to the bilayer surface. On the other hand, X-ray scattering, ${ }^{93}$ polarized ATR-FTIR, ${ }^{37} \mathrm{NMR}^{94}$ and molecular dynamics simulations ${ }^{95}$ data indicate a high degree of mobility and heterogeneity in peptide orientation in the membrane in the absence of a transmembrane potential. Therefore, the broad $\mathrm{Ph}_{\mathrm{CN}}$ absorption bandwidth observed for the AlaP analogs might also result from a significant orientational dynamics of the peptide. 


\section{CONCLUSIONS}

We synthesized and fully characterized analogs of the two long membrane-interacting peptides AlaP e TM via solution-phase synthesis or SPPS, respectively.

A detailed investigation of the aggregation, membrane-binding and membrane permeabilizing behavior of the AlaP analogs, and of the orientation of the TM peptides in membranes indicated that Phe $_{\mathrm{CN}}$ does not perturb significantly even a relatively small molecule such as an oligopeptide. The fluorescent properties of Phe $_{\mathrm{CN}}$ were extremely useful in the characterization of all these aspects. Even if no significant spectral shifts are observed for the maximum of the emission band, its intensity is highly sensitive to polarity.

All of the IR absorption spectra for peptides labeled with the Phe $\mathrm{CN}_{\mathrm{CN}}$ probe and associated to lipid bilayers exhibit a band peaked approximately between 2228 and $2230 \mathrm{~cm}^{-1}$, irrespective of the specific probe position along the sequence and peptide orientation inside the membrane. Overall, these data suggest that the position of the $\mathrm{Phe}_{\mathrm{CN}} \mathrm{IR}$ absorption band is not significantly sensitive to the depth of probe insertion in lipid membranes. However, the width of the IR absorption band increased approximately by a factor of 2 on going from a deeply inserted position to a superficial location. The FWHM parameter of the Phe $\mathrm{CN}_{\mathrm{CN}} \mathrm{IR}$ absorption band could thus represent a diagnostic indicator of positioning of the $\mathrm{Phe}_{\mathrm{CN}}$ residue inside a phospholipid bilayer. 


\section{REFERENCES}

1. Getahun, Z.; Huang, C.-Y.; Wang, T.; De Leon, B.; DeGrado, W. F.; Gai, F. J Am Chem Soc 2003, 125, 405-411.

2. Huang, C. Y.; Wang, T.; Gai, F. Chem Phys Lett 2003, 371, 731-738.

3. Tucker, M. J.; Getahun, Z.; Nanda, V.; DeGrado, W. F.; Gai, F. J Am Chem Soc 2004, 126, 5078-5079.

4. Tucker, M. J.; Oyola, R.; Gai, F. J Phys Chem B 2005, 109, 4788-4795.

5. Tucker, M. J.; Oyola, R.; Gai, F. Biopolymers 2006, 83, 571-576.

6. Tucker, M. J.; Tang, J.; Gai, F. J Phys Chem B 2006, 110, 8105-8109.

7. Schultz, K. C.; Supekova, L.; Ryu, Y.; Xie, J.; Perera, R.; Schultz, P. G. J Am Chem Soc 2006, 128, 13984-13985.

8. Tang, J.; Signarvic, R. S.; DeGrado, W. F.; Gai, F. Biochemistry 2007, 46, 13856-13863.

9. Mukherjee, S.; Chowdhury, P.; DeGrado, W. F.; Gai, F. Langmuir 2007, 23, 11174-11179.

10. Lindquist, B. A.; Furse, K. E.; Corcelli, S. A. Phys Chem Chem Phys 2009, 11, 8119-8132.

11. Aschaffenburg, D. J.; Moog, R. S. J Phys Chem B 2009, 113, 12736-12743.

12. Serrano, A. L.; Troxler, T.; Tucker, M. J.; Gai, F. Chem Phys Lett 2010, 487, 303-306.

13. Marek, P.; Mukherjee, S.; Zanni, M. T.; Raleigh, D. P. J Mol Biol 2010, 400, 878-888.

14. Taskent-Sezgin, H.; Marek, P.; Thomas, R.; Goldberg, D.; Chung, J.; Carrico, I.; Raleigh, D. P. Biochemistry 2010, 49, 6290-6295.

15. Hu, W.; Webb, L. J. J Phys Chem Lett 2011, 2, 1925-1930.

16. Xu, L.; Cohen, A. E.; Boxer, S. G. Biochemistry 2011, 50, 8311-8322.

17. Levinson, N. M.; Fried, S. D.; Boxer, S. G. J Phys Chem B 2012, 116, 10470-10476.

18. Kim, H.; Cho, M. Chem Rev 2013, 113, 5817-5847.

19. Bazewicz, C. G.; Liskov, M. T.; Hines, K. J.; Brewer, S. H. J Phys Chem B 2013, 117, 8987-8993.

20. Wissner, R. F.; Batjargal, S.; Fadzen, C. M.; Petersson, E. J. J Am Chem Soc 2013, 135, 6529-6540.

21. Levinson, N. M.; Boxer, S. G. Nat Chem Biol 2014, 10, 127-132.

22. Adhikary, R.; Zimmermann, J.; Dawson, P. E.; Romesberg, F. E. Chem Phys Chem 2014, 15, 849-853.

23. Gonzalez, J. D.; Levonyak, N. S.; Schneider, S. C.; Smith, M. J.; Cremeens, M. E. J Mol Struct 2014, 1056-1057, 7-12.

24. Ma, J. Q.; Pazos, I. M.; Gai, F. Proc Natl Acad Sci USA 2014, 111, 8476-8481.

25. Xhindoli, D.; Morgera, F.; Zinth U.; Rizzo R.; Pacor, S.; Tossi, A. Biochem J 2015, 465, 443-457.

26. Bobone, S.; Bortolotti, A.; De Zotti, M.; Ballano, G.; Formaggio, F.; Toniolo, C.; Stella, L. In Proceedings 33rd EPS, Naydenova, E.; Pajpanova, T., Eds.; European Peptide Society, 2015, in press.

27. De Zotti, M.; Bobone, S.; Bortolotti, A.; Longo, E., Biondi, B.; Peggion, C.; Formaggio, F.; Toniolo, C.; Dalla Bona, A.; Kaptein, B.; Stella, L. Chem Biodivers 2015, 12, 513-526.

28. Maienschein-Cline, M. G.; Londergan, C. H. J Phys Chem A 2007, 111, 10020-10025.

29. Fried, S. D.; Boxer, S. G. Acc Chem Res 2015, 48, 998-1006.

30. Toniolo, C.; Brückner, H. Eds.; Peptaibiotics: Fungal Peptides Containing $\alpha$-Dialkyl $\alpha$-Amino Acids; Verlag Helvetica Chimica Acta, Zürich, and Wiley-VCH, Weinheim, 2009.

31. Toniolo, C.; Brückner, H., Eds.; Peptaibiotics II; Chem Biodivers 2013, 10, issue No. 5 (Topical Issue). 
32. Nagaraj, R.; Balaram, P., Acc Chem Res 1981, 14, 356-362.

33. Fox, R. O., Jr.; Richards, F. M. Nature (London) 1982, 300, 325-330.

34. Sansom, M. S. P. Eur Biophys J 1993, 22, 105-124.

35. Kredics, L.; Szekeres, A.; Czifra, D.; Vagvölgyi, C.; Leitgeb, B. Chem Biodivers 2013, 10, 744-771.

36. Peggion, C.; Coin, I.; Toniolo, C. Biopolymers (Pept Sci) 2004, 76, 485-493.

37. Stella, L.; Burattini, M.; Mazzuca, C.; Palleschi, A.; Venanzi, M.; Coin, I.; Peggion, C.; Toniolo, C.; Pispisa, B. Chem Biodivers 2007, 4, 1299-1312.

38. Peggion, C.; Jost, M.; Baldini, C.; Formaggio, F.; Toniolo, C. Chem Biodivers 2007, 4, 1183-1199.

39. Peggion, C.; Jost, M.; De Borggraeve, W. M.; Crisma, M.; Formaggio, F.; Toniolo, C. Chem Biodivers 2007, 4, 1256-1268.

40. Crisma, M.; Peggion, C.; Baldini, C.; MacLean, E. J.; Vedovato, N.; Rispoli, G.; Toniolo, C. Angew Chem Int Ed 2007, 46, 2047-2050.

41. Milov, A. D.; Samoilova, R. I.; Tsvetkov, Y. D.; Formaggio, F.; Toniolo, C.; Raap, J. J Am Chem Soc 2007, 129, 9260-9261.

42. Marsh, D.; Jost, M.; Peggion, C.; Toniolo, C. Chem Biodivers 2007, 4, 1269-1274.

43. Milov, A. D.; Samoilova, M. I.; Tsvetkov, Y. D.; Jost, M.; Peggion, C.; Formaggio, F.; Crisma, M.; Toniolo, C.; Handgraaf, J.-W.; Raap, J. Chem Biodivers 2007, 4, 1275-1298.

44. Vedovato, N.; Baldini, C.; Toniolo, C.; Rispoli, G. Chem Biodivers 2007, 4, 1338-1346.

45. Milov, A. D.; Samoilova, R. I.; Tsvetkov, Y. D.; De Zotti, M.; Toniolo, C.; Raap, J. J Phys Chem B 2008, 112, 13469-13472.

46. Bartucci, R.; Guzzi, R.; De Zotti, M.; Toniolo, C.; Sportelli, L.; Marsh, D. Biophys J 2008, 94, 26982705.

47. Salnikov, E. S.; De Zotti, M.; Formaggio, F.; Li, X.; Toniolo, C.; O'Neil, J. D. J.; Raap, J.; Dzuba, S. A.; Bechinger, B. J Phys Chem B 2009, 113, 3034-3042.

48. Milov, A. D.; Samoilova, R. I.; Tsvetkov, Y. D.; De Zotti, M.; Formaggio, F.; Toniolo, C.; Handgraaf, J.W.; Raap, J. Biophys J 2009, 96, 3197-3209.

49. Rippa, S.; Eid, M.; Formaggio, F.; Toniolo, C.; Béven, L. ChemBioChem 2010, 11, 2042-2049.

50. Jose, R. A.; De Zotti, M.; Peggion, C.; Formaggio, F.; Toniolo, C.; De Borggraeve, W. M. J Pept Sci 2011, 17, 377-382.

51. Bobone, S.; Roversi, D.; Giordano, L.; De Zotti, M.; Formaggio, F.; Toniolo, C.; Park, Y.; Stella, L. Biochemistry 2012, 51, 10124-10126.

52. De Zotti, M.; Ballano, G.; Jost, M.; Salnikov, E. S.; Bechinger, B.; Oancea, S.; Crisma, M.; Toniolo, C.; Formaggio, F. Chem Biodivers 2014, 11, 1163-1191.

53. Bortolus, M.; Dalzini, A.; Toniolo, C.; Hahm, K.-S.; Maniero, A. L. J Pept Sci 2014, 20, 517-525.

54. Milov, A. D.; Samoilova, R. I.; Tsvetkov, Y. D.; Peggion, C.; Formaggio, F.; Toniolo, C. J Phys Chem B 2014, 118, 7085-7090.

55. Yasui, S. C.; Keiderling, T. A.; Bonora, G. M.; Toniolo, C. Biopolymers 1986, 25, 79-89.

56. Valle, G.; Crisma, M.; Toniolo, C.; Beisswenger, R.; Rieker, A.; Jung, G. J Am Chem Soc 1989, 111, 6828-6833.

57. Karle, I. L.; Balaram, P. Biochemistry 1990, 29, 6747-6756.

58. Toniolo, C.; Benedetti, E. Trends Biochem Sci 1991, 16, 350-353.

59. Bolin, K. A.; Millhauser, G. L. Acc Chem Res 1999, 32, 1027-1033.

60. Toniolo, C.; Crisma, M.; Formaggio, F.; Peggion, C. Biopolymers (Pept Sci) 2001, 60, 396-419. 
61. Toniolo, C.; Crisma, M.; Formaggio, F.; Peggion, C.; Monaco, V.; Goulard, C.; Rebuffat, S.; Bodo, B. J Am Chem Soc 1996, 118, 4952-4958.

62. Peggion, C.; Formaggio, F.; Crisma, M.; Epand, R. F.; Epand, R. M.; Toniolo, C. J Pept Sci 2003, 9, 679689.

63. De Zotti, M.; Biondi, B.; Formaggio, F.; Toniolo, C.; Stella, L.; Park, Y.; Hahm, K. S. J Pept Sci 2009, $15,615-619$.

64. Harzer, U., Bechinger, B. Biochemistry 2000, 39, 13106-13114.

65. Knorr, R.; Trzeciak, A.; Bannwarth, W.; Gillessen, D. Tetrahedron Lett 1989, 30, 1927-1930.

66. König, W.; Geiger, R. Chem Ber 1970, 103, 788-798.

67. Stella, L.; Mazzuca, C.; Venanzi, M.; Palleschi, A.; Didoné, M.; Formaggio, F.; Toniolo, C.; Pispisa, B. Biophys J 2004, 86, 936-945.

68. Bobone, S.; Gerelli, Y.; De Zotti, M.; Bocchinfuso, G.; Farrotti, A.; Orioni, B.; Sebastiani, F.; Latter, E.; Penfold, J.; Senesi, R.; Formaggio, F.; Palleschi, A.; Toniolo, C.; Fragneto, G.; Stella, L. Biochim Biophys Acta,2013, 1828, 1013-1024.

69. Stewart, J. C. M. Anal Biochem 1980, 104, 10-14.

70. Bocchinfuso, G.; Bobone, S.; Palleschi, A.; Stella, L. Cell Mol Life Sci 2011, 68, 2281-2301.

71. Roversi, D.; Luca, V.; Aureli, S.; Park, Y.; Mangoni, M. L.; Stella L. ACS Chem Biol 2014, 9, $2003-$ 2007.

72. Mazzuca, C.; Orioni, B.; Coletta, M.; Formaggio, F.; Toniolo, C.; Maulucci, G.; De Spirito, M.; Pispisa, B.; Venanzi M.; Stella, L. Biophys J 2010, 99, 1791-1800.

73. Bobone, S.; Bocchinfuso, G.; Park, Y.; Palleschi, A.; Hahm, K.-S.; Stella, L. J Pept Sci 2013, 19, 758769.

74. Lehrer, S. S.; Leavis, P. C. Methods Enzymol 1978, 49, 222-236.

75. Goormaghtigh, E.; Raussens, V.; Ruysschaert, J. M. Biochim Biophys Acta 1999, 1422, 105-185.

76. Kucerka, N.; Tristram-Nagle, S.; Nagle, J. F. J Membr Biol 2005, 208, 193-202.

77. Nagaraj, R.; Balaram, P. Tetrahedron 1981, 37, 2001-2005.

78. Brückner, H.; Currle, M. In Second Forum on Peptides; Aubry, A., Marraud, M., Vitoux, B., Eds.; Libbey Eurotext: London, 1989; pp 251-255.

79. Wenschuh, H.; Beyermann, M.; Krause, E.; Brudel, M.; Winter, R.; Schumann, M.; Carpino, L. A.; Bienert, M. J Org Chem 1994, 59, 3275-3280.

80. Formaggio, F.; Broxterman, Q. B.; Toniolo, C. In Houben-Weyl: Methods of Organic Synthesis; Synthesis of Peptides and Peptidomimetics; Goodman, M.; Felix, A.; Moroder, L.; Toniolo, C., Eds.; Vol. E22c; Thieme: Stuttgart, Germany, 2003; pp 292-310.

81. Carpino, L. A. J Am Chem Soc 1993, 115, 4397-4398.

82. Beychok, S. In Poly- $\alpha$-Amino Acids: Protein Models for Conformational Studies; Fasman, G. D., Ed.; Dekker: New York, 1967; pp 293-337.

83. Goodman, M.; Toniolo, C. Biopolymers 1968, 6, 1673-1689.

84. Manning, M. C.; Woody, R. W. Biopolymers 1992, 31, 569-586.

85. Toniolo, C.; Polese, A.; Formaggio, F.; Crisma, M.; Kamphuis, J. J Am Chem Soc 1996, 118, 27442745.

86. Pazos, I. M.; Roesch, R. M.; Gai, F. Chem Phys Lett 2013, 563, 93-96.

87. White, S. H.; Wimley, W. C. Biochim Biophys Acta 1998, 1376, 339-352.

John Wiley \& Sons, Inc. 
88. Orioni, B.; Bocchinfuso, G.; Kim, J. Y.; Palleschi, A.; Grande, G.; Bobone, S.; Park, Y.; Kim, J. I.; Hahm, K. S.; Stella, L. Biochim Biophys Acta 2009, 1788, 1523-1533.

89. Wu, Y.; Huang, H.W.; Olah, G.A. Biophys J 1990, 57, 797-806.

90. Bechinger, B. Biochim Biophys Acta 1999, 1462, 157-183.

91. Dave, P.C.; Billington, E.; Pan, Y.; Straus, S.K. Biophys J 2005, 89, 2434-2442.

92. Ye, S.; Li, H.; Wei, F.; Jasensky, J.; Boughton, A.P.: Yang, P.; Chen, Z. J Am Chem Soc 2012, 134, 6237-6243.

93. Spaar, A.; Münster, C.; Salditt, T. Biophys J 2004, 87, 396-407.

94. Bertelsen, K.; Paaske, B.; Thøgersen, L.; Tajkhorshid, E.; Schiøtt, B.; Skrydstrup, T.; Nielsen, N. C.; Vosegaard, T. J Am Chem Soc 2009, 131, 18335-18342.

95. Dittmer, J.; Thøgersen, L.; Underhaug, J.; Bertelsen, K.; Vosegaard, T.; Pedersen, J. M.; Schiøtt, B.; Tajkhorshid, E.; Skrydstrup, T.; Nielsen, N. C. J Phys Chem B 2009, 113, 6928-6937. 
Table I Acronyms and Amino Acid Sequences of the Peptides Synthesized and Studied in This Work

\begin{tabular}{|c|c|}
\hline Acronym & Amino Acid Sequence \\
\hline AlaP & $\begin{array}{l}\text { Ac-Aib-Pro-Aib-Ala-Aib-Ala-Glu(OMe)-Aib-Val-Aib-Gly-Leu-Aib-Pro-Val-Aib-Aib-Glu(OMe)-Glu(OMe)- } \\
\text { Phol }\end{array}$ \\
\hline Ala4 & $\begin{array}{l}\text { Ac-Aib-Pro-Aib-Phe }{ }_{\mathrm{CN}} \text {-Aib-Ala-Glu(OMe)-Aib-Val-Aib-Gly-Leu-Aib-Pro-Val-Aib-Aib-Glu(OMe)- } \\
\text { Glu(OMe)-Phol }\end{array}$ \\
\hline Ala9 & $\begin{array}{l}\text { Ac-Aib-Pro-Aib-Ala-Aib-Ala-Glu(OMe)-Aib-Phe }{ }_{\mathrm{cn}} \text {-Aib-Gly-Leu-Aib-Pro-Val-Aib-Aib-Glu(OMe)- } \\
\text { Glu(OMe)-Phol }\end{array}$ \\
\hline Ala15 & $\begin{array}{l}\text { Ac-Aib-Pro-Aib-Ala-Aib-Ala-Glu(OMe)-Aib-Val-Aib-Gly-Leu-Aib-Pro-Phe }{ }_{\mathrm{CN}}-\mathrm{Aib}_{\mathrm{B}} \text { Aib-Glu(OMe)- } \\
\text { Glu(OMe)-Phol }\end{array}$ \\
\hline TM & Ac-Lys-Lys-(Leu-Ala) $)_{10}$-Lys-Lys- $\mathrm{NH}_{2}$ \\
\hline TM3 & 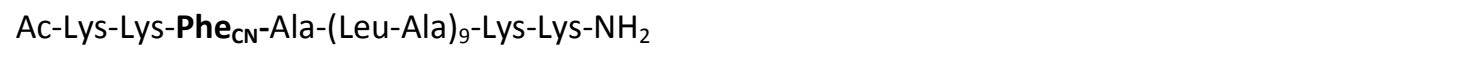 \\
\hline TM11 & Ac-Lys-Lys-(Leu-Ala) ${ }_{4}-$ Phe $_{\mathrm{CN}}$-Ala-(Leu-Ala) $)_{5}$-Lys-Lys- $\mathrm{NH}_{2}$ \\
\hline
\end{tabular}

John Wiley \& Sons, Inc. 
Table II Position and Width of the IR Absorption Band of the Cyano Probe in a Membrane Environment

\begin{tabular}{lll}
\hline Peptide & Maximum $\left(\mathrm{cm}^{-1}\right)$ & FWHM $\left(\mathrm{cm}^{-1}\right)$ \\
\hline Ala4 & 2229 & 10 \\
Ala9 & 2229 & 10 \\
Ala15 & 2229 & 11 \\
TM3 & 2228 & 10 \\
TM11 & 2230 & 6 \\
\hline
\end{tabular}

1

2

3

4

5

6

7

8

9

10

11

12

13

14

15

16

17

18

19

20

21

22

23

24

25

26

27

28

29

30

31

32

33

34

35

36

37

38

39

40

41

42

43

44

45

46

47

48

49

50

51

52

53

54

55

56

57

58

59

60

John Wiley \& Sons, Inc. 


\section{Segment A}

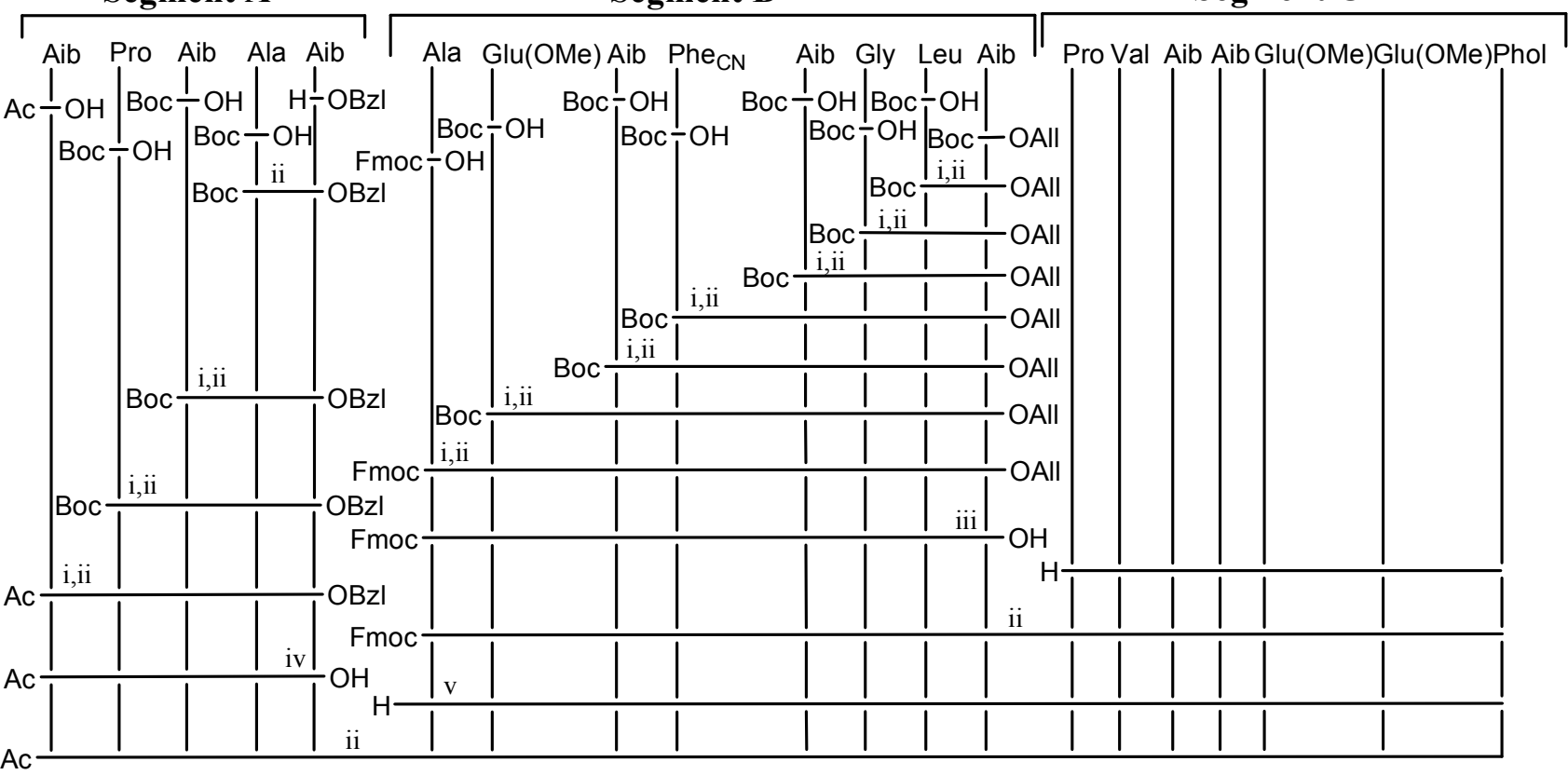

Scheme 1 Synthetic scheme used for the preparation of Ala9. (i) Boc removal upon treatment with TFA (10 eq.) in anhydrous DCM for $2 \mathrm{hr}$. (ii) Coupling reaction with EDC/HOAt; NMM was added to keep $\mathrm{pH}=8$. (iii) Treatment with $\mathrm{PhHSi}$ (2 eq.), $\mathrm{Pd}\left(\mathrm{PPh}_{3}\right)_{4}$ (0.2 eq.) in anhydrous $\mathrm{DCM}$. (iv) $\mathrm{OBzl}$ removal upon treatment with $\mathrm{H}_{2} / \mathrm{Pd}$ in $\mathrm{MeOH}$. (vi) Fmoc removal upon treatment with diethylamine in DCM, followed by flash chromatography. 


\begin{tabular}{|c|c|c|c|}
\hline \multirow{3}{*}{ Ala4 } & 1234 & $\begin{array}{llllllll}6 & 7 & 8 & 9 & 10 & 11 & 12 & 13\end{array}$ & $\begin{array}{lllllll}14 & 15 & 16 & 17 & 18 & 19 & 20\end{array}$ \\
\hline & $A c-U P$ P Phe $e_{C N} U$ & 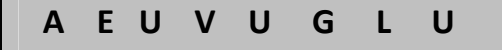 & $\begin{array}{lllllll}P & V & U & U & E & E & \text { Phol }\end{array}$ \\
\hline & Segment A & Segment B & Segment C \\
\hline
\end{tabular}

\begin{tabular}{|c|c|c|c|}
\hline \multirow{3}{*}{ Ala9 } & $\begin{array}{lllll}1 & 2 & 3 & 4 & 5\end{array}$ & 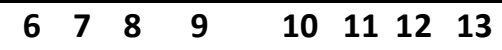 & $\begin{array}{lllllll}14 & 15 & 16 & 17 & 18 & 19 & 20\end{array}$ \\
\hline & $A c-U \quad P \cup A U$ & A E U Phe $e_{C N} U$ G L $\quad$ U & $\begin{array}{lllllll}P & V & U & U & E & E & \text { Phol }\end{array}$ \\
\hline & Segment A & Segment B & Segment C \\
\hline
\end{tabular}

\begin{tabular}{|c|c|c|c|}
\hline \multirow{3}{*}{ Ala15 } & $\begin{array}{lllll}1 & 2 & 3 & 4 & 5\end{array}$ & $\begin{array}{llllllll}6 & 7 & 8 & 9 & 10 & 11 & 12 & 13\end{array}$ & $\begin{array}{lllllll}14 & 15 & 16 & 17 & 18 & 19 & 20\end{array}$ \\
\hline & $A C-U P U A U$ & 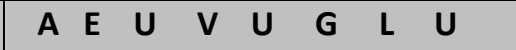 & P Phe CN U U E E Phol \\
\hline & Segment A & Segment B & Segment C \\
\hline
\end{tabular}

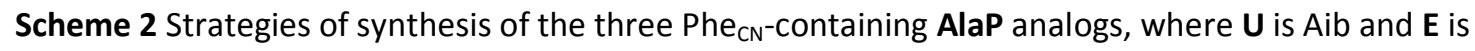
Glu(OMe). 


\section{FIGURE LEGENDS}

Figure 1 Fluorescence emission spectra of the AlaP analogs: Ala4 (full line), Ala9 (dashed line), Ala15 (dotted line). Conditions: $\lambda_{\text {exc. }}=240 \mathrm{~nm}$, room temperature, $10 \mathrm{mM}$ phosphate buffer, $140 \mathrm{mM}$ $\mathrm{NaCl}, 0.1 \mathrm{mM}$ EDTA (pH 7.4). Peptide concentration $1 \mu \mathrm{M}$.

Figure 2 Far-UV CD spectra of AlaP and its three analogs in $\mathrm{MeOH}$ solution (A) and $100 \mathrm{mM} \mathrm{SDS}$ in $\mathrm{H}_{2} \mathrm{O}$ (B), and of TM and its two analogs in $\mathrm{MeOH}$ solution (C) and 100mM SDS in $\mathrm{H}_{2} \mathrm{O}$ (D). Peptide concentration: $0.1 \mathrm{mM}$.

Figure 3 Time-resolved fluorescence decays of Ala9 at different peptide concentrations: $0.19 \mu \mathrm{M}, 1.15$ $\mu \mathrm{M}$, and $19.2 \mu \mathrm{M}$. Conditions: $\lambda_{\text {exc. }}=240 \mathrm{~nm} ; \lambda_{\text {em. }}=295 \mathrm{~nm}$, room temperature, $10 \mathrm{mM}$ phosphate buffer, $140 \mathrm{mM} \mathrm{NaCl}, 0.1 \mathrm{mM}$ EDTA (pH 7.4).

Figure 4 Aggregated peptide fractions as a function of peptide concentration for AlaP (full circles), and its analogs Ala4 (empty circles), Ala9 (empty squares), and Ala15 (empty diamonds). The full line represents just a guide for the eye.

Figure 5 Fluorescence emission spectra of Ala15 $(1 \mu \mathrm{M})$ in the absence and presence of increasing lipid concentrations. Conditions: [POPC] $=$ from 0.1 to $50 \mu \mathrm{M} ; \lambda_{\mathrm{exc}}=240 \mathrm{~nm}$; liposome diameter: 100 $\mathrm{nm} ; \mathrm{T}: 25^{\circ} \mathrm{C}$.

Figure 6 Membrane-bound peptide fraction as a function of [POPC] lipid concentration for Ala4 (empty circles), Ala9 (empty squares), and Ala15 (empty diamonds); [peptide] = $1 \mu \mathrm{M}$. The full line represents a global fit to all data (see Materials and Methods).

Figure 7 Peptide-induced leaked fraction as a function of peptide concentration for AlaP (full circles), and its analogs Ala4 (empty circles), Ala9 (empty squares), and Ala15 (empty diamonds). Conditions: $\lambda_{\text {exc. }}=490 \mathrm{~nm} ; \lambda_{\text {em. }}=520 \mathrm{~nm}$; [POPC]: $20 \mu$ M; Liposome diameter: $200 \mathrm{~nm}$.

Figure 8 Stern-Volmer plot of TM3 (empty circles, dotted line) and TM11 (full circles, full line) in presence of increasing amounts of $\mathrm{KCl}$. $\mathrm{F}_{0}$ and $\mathrm{F}$ indicate the fluorescence intensities in the absence and presence of quencher, respectively. The solid lines represent fits to the data according to the model described in Materials and Methods.

Figure 9 Polarized ATR-FTIR spectra of TM3 in POPC membranes (P/L 5\%) in the amide I region. The full and dashed lines represent the spectra collected with parallel and perpendicular polarization with respect to the plane of incidence, respectively. The ratio of the absorbance values obtained in the two spectra (dichroic ratio) indicates a transmembrane orientation (see Results and Discussion).

Figure 10 ATR-FTIR spectrum of Ala15 in POPC lipids at P/L 15\%.

Figure 11 Phe $_{\mathrm{CN}}$ absorption band of TM3 (empty circles, dashed line) and TM11 (full circles, solid line) in POPC at P/L=5\%. Circles: experimental data: lines: Gaussian fits. 
1

2

3

4

5

6

7

8

9

10

11

12

13

14

15

16

17

18

19

20

21

22

23

24

25

26

27

28

29

30

31

32

33

34

35

36

37

38

39

40

41

42

43

44

45

46

47

48

49

50

51

52

53

54

55

56

57

58

59

60

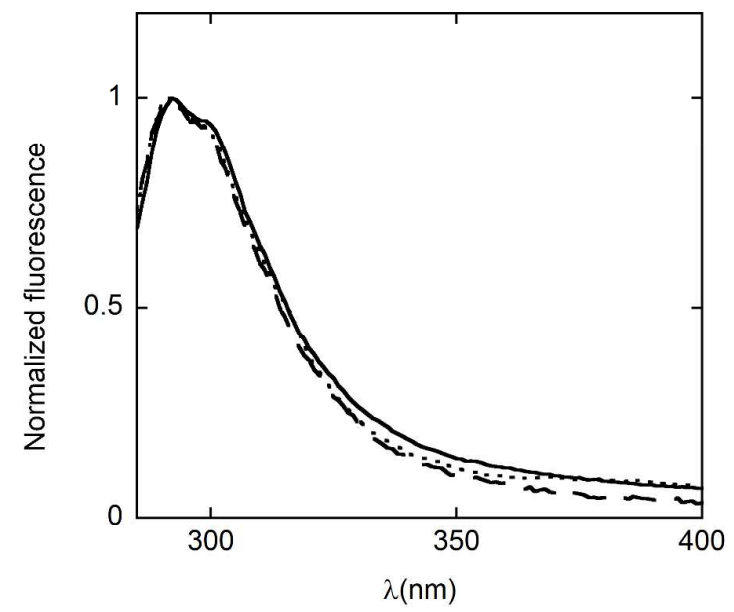

Figure 1

John Wiley \& Sons, Inc. 

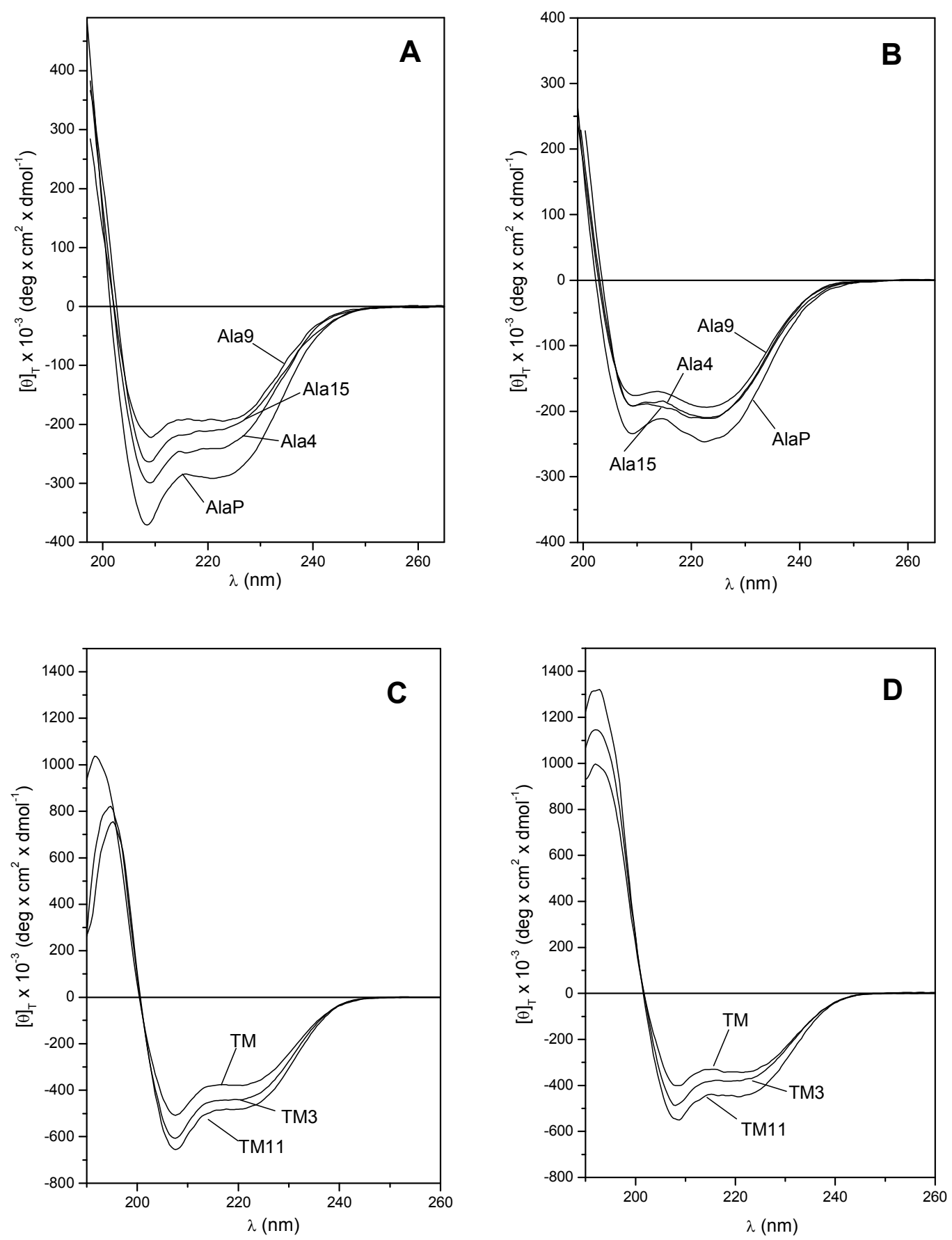

Figure 2

John Wiley \& Sons, Inc. 
1

2

3

4

5

6

7

8

9

10

11

12

13

14

15

16

17

18

19

20

21

22

23

24

25

26

27

28

29

30

31

32

33

34

35

36

37

38

39

40

41

42

43

44

45

46

47

48

49

50

51

52

53

54

55

56

57

58

59

60

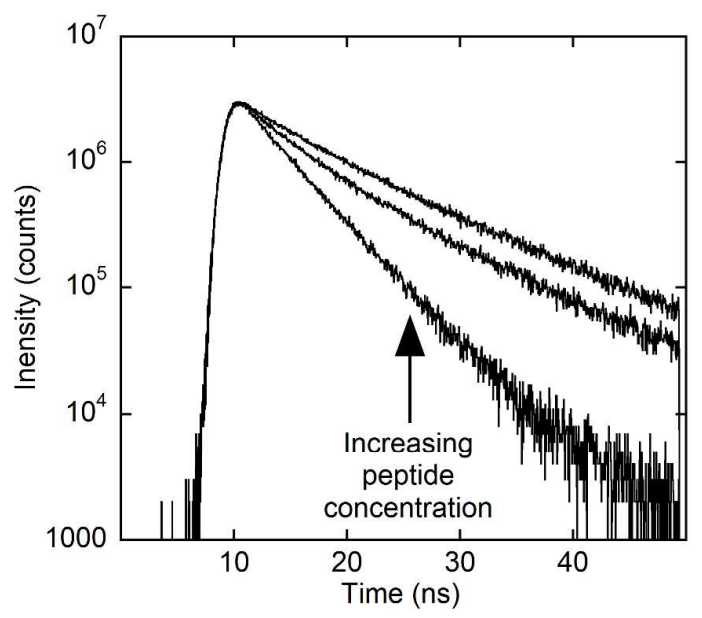

Figure 3

John Wiley \& Sons, Inc. 
1

2

3

4

5

6

7

8

9

10

11

12

13

14

15

16

17

18

19

20

21

22

23

24

25

26

27

28

29

30

31

32

33

34

35

36

37

38

39

40

41

42

43

44

45

46

47

48

49

50

51

52

53

54

55

56

57

58

59

60

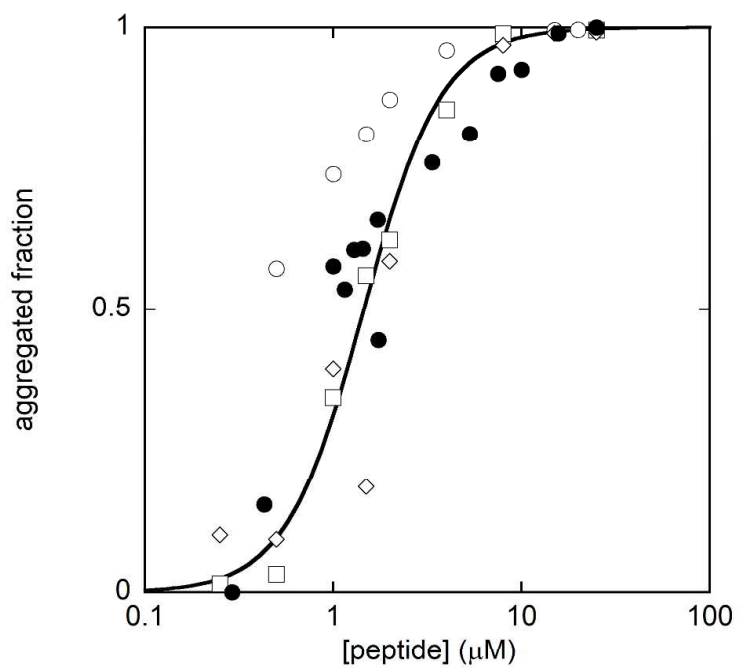

Figure 4

John Wiley \& Sons, Inc. 
1

2

3

4

5

6

7

8

9

10

11

12

13

14

15

16

17

18

19

20

21

22

23

24

25

26

27

28

29

30

31

32

33

34

35

36

37

38

39

40

41

42

43

44

45

46

47

48

49

50

51

52

53

54

55

56

57

58

59

60

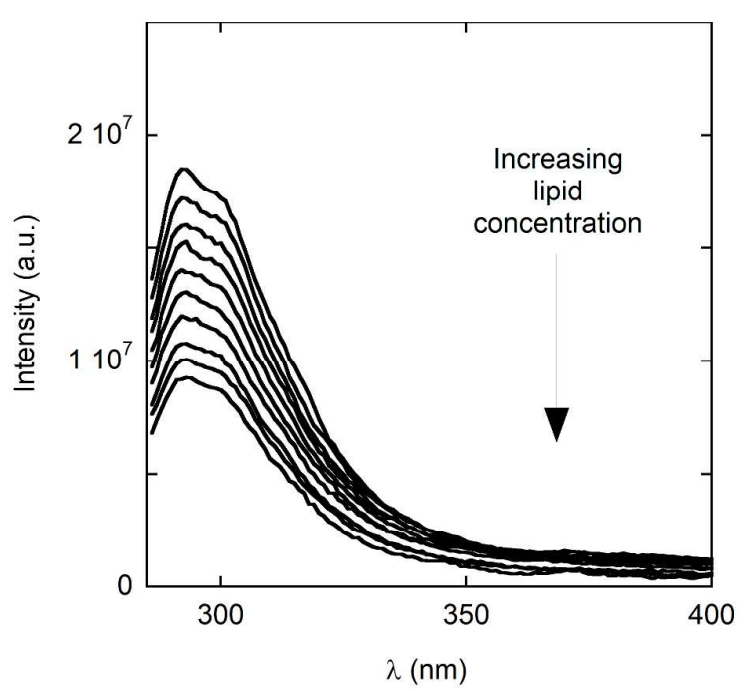

Figure 5

John Wiley \& Sons, Inc. 
1

2

3

4

5

6

7

8

9

10

11

12

13

14

15

16

17

18

19

20

21

22

23

24

25

26

27

28

29

30

31

32

33

34

35

36

37

38

39

40

41

42

43

44

45

46

47

48

49

50

51

52

53

54

55

56

57

58

59

60

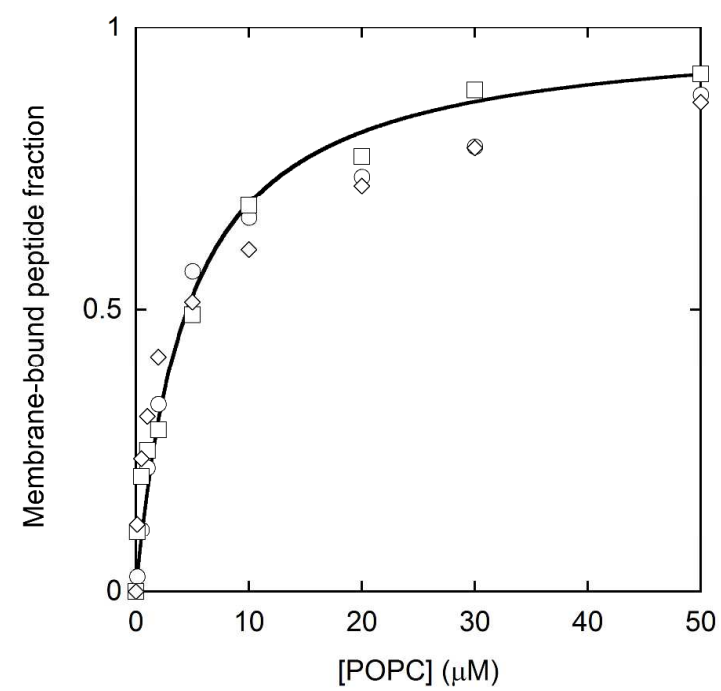

Figure 6

John Wiley \& Sons, Inc. 
1

2

3

4

5

6

7

8

9

10

11

12

13

14

15

16

17

18

19

20

21

22

23

24

25

26

27

28

29

30

31

32

33

34

35

36

37

38

39

40

41

42

43

44

45

46

47

48

49

50

51

52

53

54

55

56

57

58

59

60

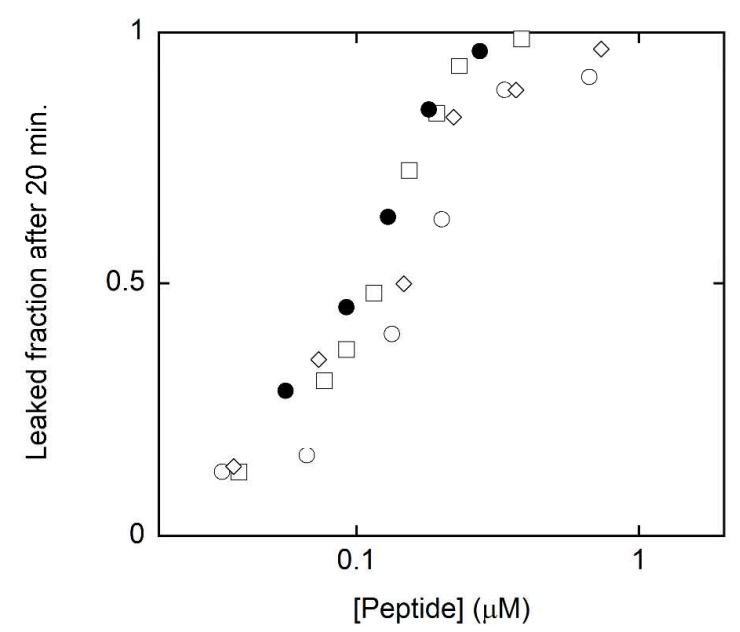

Figure 7

John Wiley \& Sons, Inc. 
1

2

3

4

5

6

10

11

12

13

14

15

16

17

18

19

20

21

22

23

24

25

26

27

28

29

30

31

32

33

34

35

36

37

38

39

40

41

42

43

44

45

46

47

48

49

50

51

52

53

54

55

56

57

58

59

60

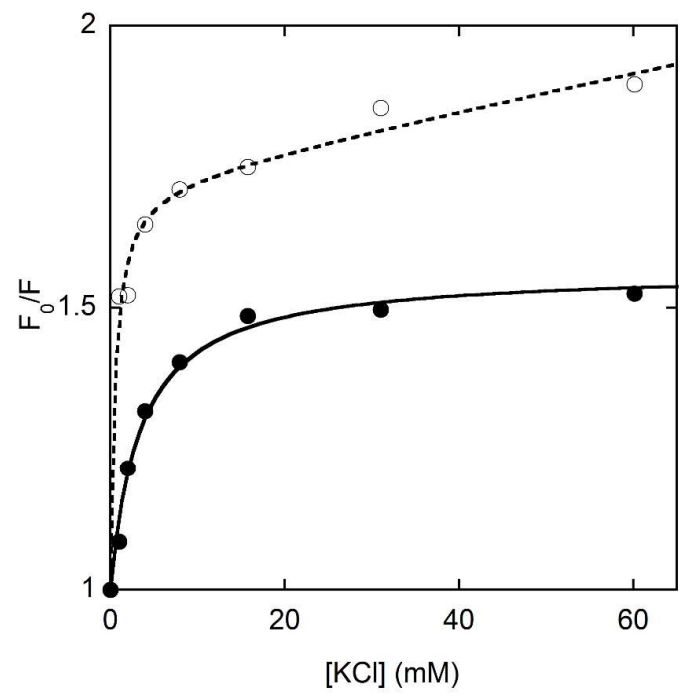

Figure 8

John Wiley \& Sons, Inc. 
1

2

3

4

5

6

7

8

9

10

11

12

13

14

15

16

17

18

19

20

21

22

23

24

25

26

27

28

29

30

31

32

33

34

35

36

37

38

39

40

41

42

43

44

45

46

47

48

49

50

51

52

53

54

55

56

57

58

59

60

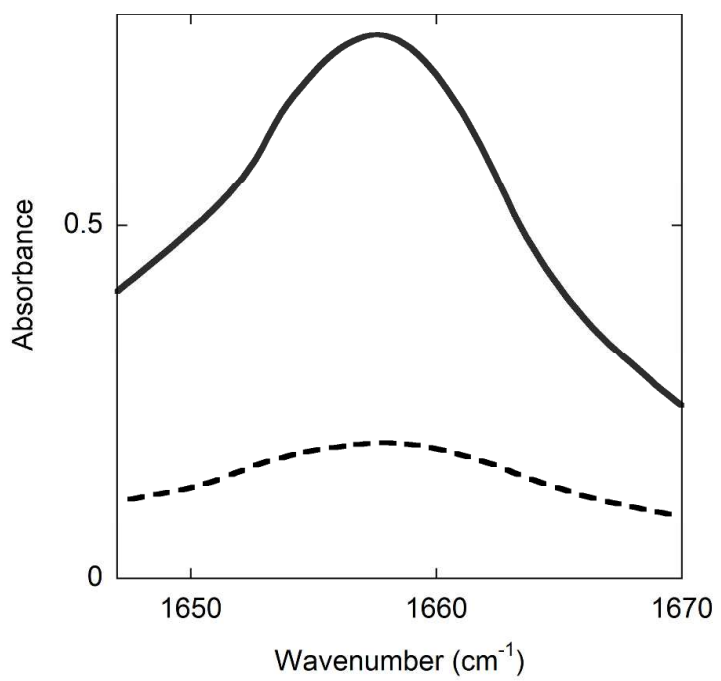

Figure 9

John Wiley \& Sons, Inc. 
1

2

3

4

5

6

7

8

9

10

11

12

13

14

15

16

17

18

19

20

21

22

23

24

25

26

27

28

29

30

31

32

33

34

35

36

37

38

39

40

41

42

43

44

45

46

47

48

49

50

51

52

53

54

55

56

57

58

59

60

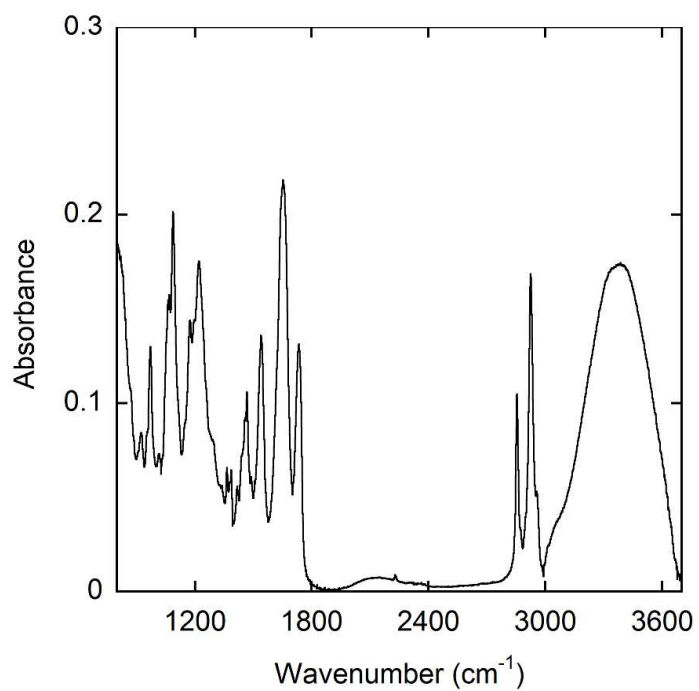

Figure 10

John Wiley \& Sons, Inc. 
1

2

3

4

5

6

7

8

9

10

11

12

13

14

15

16

17

18

19

20

21

22

23

24

25

26

27

28

29

30

31

32

33

34

35

36

37

38

39

40

41

42

43

44

45

46

47

48

49

50

51

52

53

54

55

56

57

58

59

60

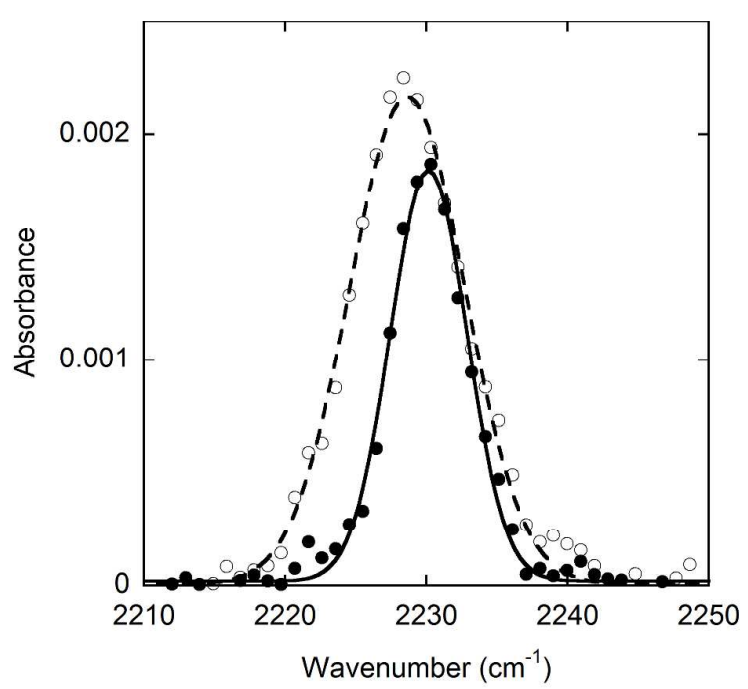

Figure 11

John Wiley \& Sons, Inc. 